\title{
Minority Politics Courses: Moving Beyond Controversy and Toward Active Learning*
}

\author{
Yvette Alex-Assensoh, Indiana University
}

In this article I discuss how courses dealing with issues of race, ethnicity, gender, and sexual orientation differ from traditional political science courses. I also describe my efforts to help students develop the analytical skills they need to productively explore controversial topics in minority politics and other courses. Most importantly, I identify several useful pedagogical strategies for promoting active and collaborative learning through open and respectful discussion.

Minority politics courses, unlike most political science courses, compel students and teachers alike to contend with cognitive and affective issues. Whereas students taking an international relations class are rarely asked to do more than analyze and critique theoretical descriptions of political institutions and behaviors, students taking a minority politics class engage issues that, very often, cause them to question their own identities, family values, belief systems, and policy dispositions. This is certainly true for students enrolled in my undergraduate course, Outsider Politics: How Minorities Play the Political Game, which confronts them with information that supports and contradicts their own policy positions and, in turn, gener-

Yvette Alex-Assensoh conducts research and publishes in the areas of urban politics, minority politics and political behavior. Her research has been supported by grants from the National Science Foundation, National Academy of Education/ Spencer Foundation, Ford Foundation and the Social Science Research Council. She is author of Neighborhoods, Family and Political Behavior in Urban America (Garland, 1998) and coeditor of the forthcoming Black and Multiracial Politics in America (NYU Press, 2000). She is also the current book review editor of Urban Affairs Review. ates high levels of discomfort and

controversy.

When taking my course, students who oppose ameliorative government policies intended specifically to aid racial and ethnic minorities are "forced" (to use a familiar student lament) to reckon with the copious research on the active role government has played in perpetuating racial discrimination, as well as the evidence of continuing educational, economic, and social inequalities endured by minority group members. The course materials also prompt students who believe that racism is the greatest impediment to the progress of minorities to deal with data showing high rates of success for anyone, regardless of race, with college degrees or advance technical skills. Most of my students find themselves unable to deal with these topics in purely analytic ways and the emotions stirred by their reading and research often boil over into the classroom and manifests itself in controversy, anger, guilt, resentment, and, in some cases, complete silence.

Unlike instructors of courses dealing with international relations, Congress, or political behavior, teachers of courses on minority politics cannot legitimately prevent classroom conflict by avoiding such emotionladen and controversial issues as gay and lesbian rights, affirmative action, immigration, and school choice. Since students invariably harbor strong biases and dispositions (frequently based more on half-truths and emotion than hard-core intellectual analyses of factual information) regarding the subjects treated in my course, tension is inevitable.

Over the years, I have noticed that nonminority students tend to approach my class with one of three perspectives: They arrive as flag bearers for and defenders of their race, as apologizers willing to blame members of their race for every instance of evil and socioeconomic injustice, or as nonchalant observers unwilling to fully participate in a class they want to conclude as quickly and painlessly as possible. On the other hand, I have also noticed that some minority students tend to enter Outsider Politics with an empty air of authority; they act as though their status as a member of a minority group authenticates their opinions as indisputable facts. In truth, many minority and nonminority students have come to my class well versed in superficial knowledge about the issues to be covered but knowing very little about the dynamics and history of racial and ethnic politics. I have met very few students who have been willing, initially at least, to acknowledge the weaknesses of their positions. Hard experience has taught me that failing to address individual students' unproductive attitudes and factual blind spots can derail the collaborative learning process for all students.

Teachers of minority politics courses face many challenges. One of the most difficult is that students may limit their participation in or unnecessarily tailor their comments during class discussions in an effort to appear politically correct in the eyes of their peers. This problem can become especially acute when, like me, the instructor is a member of one or more of the minority groups being discussed. A second concern is that students may view the teacher of such a course as a bearer of bad tidings, unwilling to accept any but her own (perceived) negative assessments of minoritynonminority relations. Students who feel their contributions will not be 
valued or given the hearing they deserve may vent their frustrations by refusing to participate in or trying to undermine class discussions, being uncivil toward the teacher and their peers, or submitting undeservedly harsh end-of-semester evaluations of the instructor and the course.

I have faced all of these challenges while teaching Outsider Politics over the past six years.

While I will not claim to have overcome them all, I have had some success in preventing students' emotions from overriding their intellects by employing pedagogical strategies that facilitate active learning through participation. By using a mixture of lectures, in-class writing assignments, structured debates, role plays, guided discussions, and outof-class group research projects, I have found it possible to move students to a level of engagement with the subject matter at which they "own" the information and concepts they encounter. By requiring students to think creatively about minority politics, I lead them to a fuller understanding of issues and, hopefully, help them develop skills they will find useful when taking other political science courses.

As a first step toward achieving these outcomes, I strive to create a classroom environment conducive to critical thinking and to build among students an expectation of equal and active participation.

\section{Creating a Foundation for Active and Collaborative Learning}

As I noted above, many students bring strong biases and a wealth of misinformation to my classroom, which invariably undermine the collaborative learning process. Know-itall students who feel they are experts on minority politics have the ability to silence other students by forcefully presenting their opinions as facts. Similarly, some students who are overly concerned with appearing politically correct can "kill" a discussion by explicitly or implicitly declaring too many topics or opinions taboo. While I certainly make it clear that students must accord each other respect and observe the norms of classroom decorum, I also continually remind them that voicing sentiments that some of their peers may consider inappropriate or offensive is crucial to their learning processes. I tell them further that bringing all misunderstandings to light is essential if they ever want to fully understand and fully appreciate controversial issues.

As an antidote for know-it-all attitudes, I have developed a means for "leveling the playing field" in the classroom by proving to students that they all have a great deal to learn about minority politics and assuring them that, if they complete the assigned reading material, they will be able to contribute meaningfully to class discussions.

During the first or second class meeting, I administer a brief quiz with the intention of gauging what the students already know as well as demonstrating to them how much they do not know about minority politics, and especially about the concerns of Asians, Latinos, and gays and lesbians. The quiz is anonymous, but the answers are shared with the class. I ask students to identify themselves only by the last four digits of their social security numbers, collect the completed quiz$z e s$, and randomly redistribute the quizzes to fellow students for grading. I then ask the graders to announce how many correct answers appear on the quizzes they have handled.

While the exercise does much to preclude students from according expert status to any of their peers, its real purpose is to introduce students to the sheer complexity of minority politics by underscoring how many issues and policies do not lend themselves to facile analyses or ready solutions. It serves as a first indication of the extent to which conventional wisdom can be inaccurate. For example, when asked to identify the racial group that earns the highest mean family income in America, most students automatically identify whites. The correct answer, however, is Asians (AlexAssensoh and Hanks 2000, Intro.; McClain and Stewart 1999, 30). Also, when answering questions about political ideology, students identify blacks as liberal across the board. In reality, political surveys and opinion polls invariably demonstrate that blacks are liberal on economic issues but much more conservative on social and moral issues (Alex-Assensoh and Hanks 2000, Intro.; Dawson 1994; McClain and Stewart 1999, 66-67).

To take one last example, the quiz reveals to students that much of what they think they know about welfare participation is inaccurate. No doubt influenced by stereotypical news and entertainment media images, students identify blacks as the primary recipients of welfare benefits. However, data from the Census Bureau and other government agencies show that a majority of welfare recipients are white. The secondlargest group of welfare recipients are blacks, followed by Latinos and Asians (Chideya, 1995, 37).

Getting students to realize that conventional wisdom and politically correct answers are often erroneous makes them eager to learn the right answers. To fully engage the information they will encounter, however, students must become conscious of how they identify themselves culturally, racially, and ethnically.

At the beginning of the first class meeting, I make it clear to students that each person in the room possesses at least a dual identity; that, at a minimum, every person is simultaneously a member of at least two, and usually more, racial, ethnic, gender, and socioeconomic groups. To help them come to terms with this concept, I ask students to write, in class, a single paragraph answer to the following questions: How do you identify yourself racially, ethni- 
cally, and in terms of gender, socioeconomic status, and sexual identity? What were the circumstances that compelled or encouraged you to identify yourself in these ways? How do you feel about those circumstances? After giving students about 15 minutes to draft their answers, I ask them to form groups of three or four and discuss their answers. I also request that volunteers share their identifications with the entire class.

I am always pleased to note that the students' brief essays foreshadow the introduction of such course themes as the social construction of identity, assimilation, and discrimination. By first discussing these issues with reference to themselves and their own experiences, students are allowed to tap into some of the raw emotions engendered by racial, ethnic, gender, and sexual identity and are also given a chance to observe how these tough topics can be addressed in a civil and respectful way.

\section{Promoting Critical Thinking, Engaging Discussion, and Effective Writing through Balanced Reading}

To facilitate critical thinking and productive class discussions, I assign a broad range of readings that cover the historical background of an issue and treat it from conservative, liberal, and moderate perspectives. In the past, I have used Ronald Takaki's $A$ Different Mirror: $A$ History of Multicultural America (Little, Brown, 1993) to provide historical perspective. More recently, I have found Paula McClain and Joseph Stewart Jr.'s Can
We All Get Along? Racial and Ethnic Minorities in American Politics

(Westview, 1999) a useful text for this purpose. Another good text for advanced undergraduate and graduate classes is my and Lawrence

Hanks' forthcoming Black and Multiracial Politics in America (NYU Press, 2000). I also usually ask students to read essays from the Opposing Viewpoints series on immigration, civil liberties, affirmative action, immigration, homosexuality, and race relations to expose them to the various interpretations of difficult issues. Supplemental readings from current newspapers and magazines are assigned as appropriate.

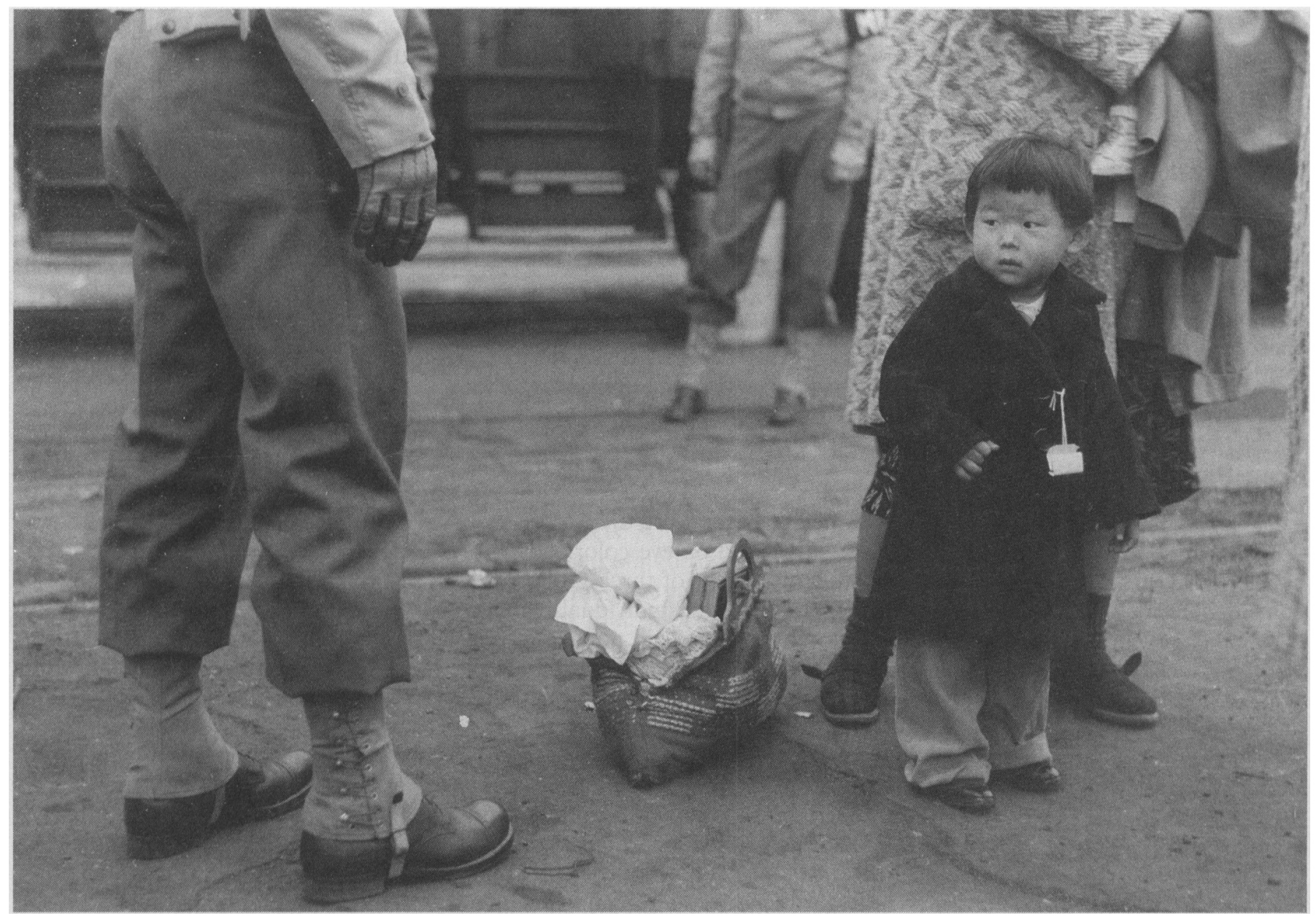

Japanese-American child en route to internment camp during World War II. 
By giving equal voice to writers across the political continuum, I seek to lead students to understand that most issues in minority politics do not lend themselves to simple, best solutions. I also want to provide students with various legitimate ideological and theoretical perspectives from which they can contribute to discussions. It is important for students to understand that a variety of informed opinions exist on most issues and that "referring to the literature" is always preferable to merely voicing impressions.

I have learned, of course, that it takes more than assembling a good reading list to provoke engaging discussions and critical thinking. That is why I often couple reading assignments with short writing exercises. Requiring students to compare and contrast, summarize, synthesize, or critique a reading gives them an opportunity to develop critical thinking and writing skills. More importantly, the writing assignments give students an opportunity to productively channel the rage, guilt, resentment, or victimization they may feel after reading the assigned texts before coming to class.

Unfortunately, even discussions informed by reliable sources and focused by thoughtful personal reflection can degenerate into series of senseless sound bites and insensitive comments. For this reason, I have found it helpful to structure in-class discussions using debates and role plays.

\section{Using Debates and Role-Play Activities to Facilitate Discussion and Active Learning}

Over the years, I have had students debate such issues as the longterm effects of slavery, the payment of reparations to Japanese Americans interned during World War II, the desirability of affirmative action, the constitutionality of Propositions 187 and 209, the reasonableness of the decisions reached by the Supreme Court in Shaw v. Reno and the Hopwood case (Texas et al. v. Cheryl J. Hopwood et al.), and the causes as well as the effects of the multiethnic riots in Los Angeles following the announcement of the decision in the first Rodney King police brutality case.

For each debate, I divide students into "pro" and "con" teams and ask them to research their positions and present their best arguments for them. Occasionally, to ensure students are exposed to a variety of perspectives, I stage "reverse" debates. After determining which positions students agree with, I insist that they prepare and present a case for the position counter to their own. By staging such reverse debates, I appeal to students' competitive nature in an effort to get them to take seriously opinions with which they disagree: They will not be able to win the debate if they do not demonstrate an understanding of opinions they do not share.

However they are staged, debates allow students to sort through the affective components of controversial issues and to analyze the strengths and weaknesses of the reasons people give for holding the opinions they do. Role-playing exercises, on the other hand, have proved valuable for helping students achieve a personal understanding of crucial concepts like color consciousness, racism, and discrimination, as well as the long-term effects of each. Of the role-playing exercises I have used, the one that worked best-in terms of conveying the consequences of racial disparities in political power and socioeconomic resources- has been dividing students into "hair-color societies."

Following the example of the classical sociological experiment in which students were divided into groups based on eye color, I assign students to one of three groups on the basis of their individual hair colors. The groups hold political power in direct proportion to the darkness of their members' hair: the darker the hair, the greater the group's power.

Over the course of the semester, each group is required to deal with issues of political participation, intergroup relations, and public policy regarding education, employment, and housing. I will begin a typical class session devoted to the roleplaying exercise by stating a problem and then asking the students to form their societies and develop role-appropriate responses to it. The most powerful group is required to prepare legislation or a referendum, effectively limiting how the less-powerful groups may respond to the larger challenge. The two less-powerful groups must then try to achieve their best outcomes while working within the strictures imposed by the most powerful group. The results are not always encouraging.

Too often, the group with the most power has worked to strengthen its position of privilege at the expense of the other groups-a pattern observed frequently in the real world. The two less-powerful groups have also exhibited a tendency to advance their own particular concerns rather than working together to achieve optimal results for all. Only rarely have the lesspowerful groups coordinated their efforts to win mutually beneficial concessions from the foremost group.

"Living" for a semester as members of groups relatively advantaged or disadvantaged on the basis of an arbitrary-but-visible characteristic like hair color helps students realize that race- or ethnicity-based prejudice has profound consequences for the distribution of political power, socioeconomic status, and group identity. It also helps them see how empowerment and disempowerment are cyclical phenomena. They become, in some instances, operators of the mechanisms the more powerful use to keep their power and, in other instances, the victims of a system that either denies the less powerful an opportunity to gain power or encourages them to squander what little power they are able to exercise by fostering disorganization and rewarding self-interest. Finally, working to improve their group's prospects teaches students important lessons about how public policies are made, the importance and pitfalls of coalition building, and the impact political decisions can have on citizens (see Fleming and Levie 1978, 232-33; Jennings 1994; Rich 1996). 


\section{Using Autobiographies and Videos to Give Voice to Minority Perspectives}

As a result of the segregated nature of American society, students have very few opportunities to engage in meaningful interethnic exchange and dialogue, even in classrooms. The resultant social distance makes most individuals dependent on the news and entertainment media for information on people of races, ethnicities, and genders different from their own. Exposed only to mythologized and usually unflattering stereotypical images of "others," students can find it easy to forget that all people, regardless of backgrounds, share similar human experiences and emotions. Frequently, my classroom will be the first place students will have had a chance to interact meaningfully with peers from racial and ethnic groups different from their own.

While textbooks on minority politics do an excellent job of familiarizing students with important concepts, issues, and historical background, memoirs written by black, Asian, Latino, Native American, and gay and lesbian individuals can give topics a human face. Accordingly, I ask students to read one autobiography and to work with three or four of their classmates to present an important theme to the class in a creative format. In the past, students' choices have included Life on the Color Line: The True Story of a White Boy Who Discovered He Was Black (Penguin, 1995); The Autobiography of Malcolm X (Ballantine, 1992); The Rice Room: Growing Up Chinese American (Penguin, 1995); Japanese by Spring (Penguin, 1993); and How the Garcia Girls Lost Their Accents (Plume, 1992). Each of these books personalizes experiences of political disempowerment, economic deprivation, discrimination, educational inequality, and racism and illustrates how each has the potential for breaking the human spirit and dividing families.

Students have conducted mock interviews with authors, reenacted dramatic scenes, and, most inventively, staged a game show during which contestants revealed factual information from the chosen book. Overall, students have praised this exercise as fundamental for helping them understand how core course concepts are experienced in the everyday life of individuals.

I have also used videos to give voice to Native Americans espousing their views regarding the sanctity of nature and man's inextricable link to the earth, to whites who feared electing blacks as mayors of their cities, to residents of a deteriorating innercity neighborhood, to Latino immigrants in California struggling to acculturate without surrendering their original identities, and to Japanese Americans interned during World War II. The images in the videos serve as powerful stimulants for discussion. Students have been especially moved by Among Brothers: Politics in New Orleans (PBS Video, 1986); Between Two Worlds: A Documentary (University of California Extension Center for Media and Independent Learning, 1998); Goin' to Chicago (California Newsreel, 1994); Hispanics, Their Differences: Myth or Fact (Films for Humanities and Sciences, 1998); and Columbus Did Not Discover Us (Turning Tide Productions, 1992).

\section{Inquiry Group Projects}

The cornerstone of my course is a semester-long group research project. At the beginning of each term, I ask each student to submit a list of what he or she considers to be the most pressing and important problems in minority politics. From these, I compile a master list of topics from which the students choose first and second preferences for research projects.

Using their stated preferences as a guide, I assign students to groups of three or four to begin work on their chosen theme. As first steps, each group is required to narrow their topics to one or two researchable questions and prepare contracts stipulating each group members' responsibilities. Groups are expected to produce annotated bibliographies between three and four pages in length. They are also required to present their most interesting find- ings to the class in an innovative format. Students have met this last challenge by delivering multimedia presentations, staging plays, conducting surveys, and producing mock Oprah-style talk shows. In addition to the group work, each student is required to write a five- to sevenpage essay in which she provides an individual analysis of the chosen research question.

Inquiry group projects can be useful in all college courses, but are particularly suited to minority politics courses since students come to them with their own strong biases and opinions about policy issues. The projects prompt students to complete detailed research on all aspects of controversial issues, giving students opportunities to hone their research skills and learn that complex questions require complex answers.

\section{When Controversy Erupts in the Classroom}

Given the topics I ask them to address, it is inevitable that some students will ex press outright racist, prefudicial, and homophobic sentiments offensive to others. When this happens, my first reaction is to remain silent and give the offending student an opportunity to retract or rephrase his or her original statement. I act on the assumption that, in the heat of debate, the student said something that he or she did not really mean. When students do not readily take advantage of the opportunity to "save" themselves, I will sometimes interrupt class discussion, repeat or have another student repeat the offensive statement, and explicitly ask the offending student to justify, moderate, or retract the statement (Frederick 1995, 91).

I have learned, however, that in most instances it is most instructive to let the discussion continue until a student offended by an earlier statement voices his or her discomfort or displeasure. I do require students voicing offense to explain exactly why they took offense, but do not place undue restrictions on $\mathrm{ex}$ changes among students. I am al- 
ways pleased when students draw upon course materials to analyze the use of language as a tool for empowerment and alienation.

In a nutshell, I strive to make my classroom an incubator for "hatching" democratic minds and a toler-

\section{Note}

${ }^{*}$ An earlier draft of this essay benefitted from the pedagogical insights and suggestions of Indiana University's Teaching Resources Center Director Joan Middendorf and edito-

\section{References}

Alex-Assensoh, Yvette, and Lawrence Hanks. 2000. Black and Multiracial Politics in America. New York: New York University Press.

Alvarez, Julia. 1991. How The Garcia Girls Lost Their Accent. Chapel Hill, NC: Algonquin Books.

Chideya, Farai. 1995. Don't Believe the Hype. New York: Penguin Group.

Dawson, Michael C. 1994. Behind the Mule: Race and Class in African-American Politics. Princeton: Princeton University Press.

Fleming, Malcolm, and W. Howard Levie. 1978. Instructional Message Design: Principles from the Behavioral Sciences. Englewood Cliffs, NJ: Educational Technology Publications.

\section{Videos}

Among Brothers: Politics in New Orleans. 1986. Arlington, VA: PBS Video.

Between Two Worlds: A Documentary. 1998. Berkeley, CA: University of California Extension Center for Media and Independent Learning. ant citizenry. I believe that, in the long run, it is more important to insist that students collaborate with ideological, partisan, racial, ethnic, and sexual others in learning about minority politics, and to risk being offended and insulted, than it is to

rial encouragement from Professor A.B. Assensoh of Indiana University. I am grateful to Indiana University's College of Arts and Sciences for funding my development of one of keep lessons and discussions limited to "safe" subjects. I work to conduct a class that provides students with the skills they will need to go into the world outside the classroom to work, live, compete, and thrive in America's multi-everything society. my minority politics courses and my colleagues in IU's political science department for encouraging me to develop and teach courses on minority politics.
Fong-Torres, Ben. 1994. The Rice Room: Growing Up Chinese-American; From Number Two Son to Rock ' $N$ ' Roll. New York: Penguin Group.

Frederick, Peter. 1995. "Walking on Eggs: Mastering the Dreaded Diversity Discussion." College Teaching 43(3): 83-92.

Howard, Gregory. 1995. Life on the Color Line: The True Story of a White Boy Who Discovered He Was Black. New York: Penguin Group.

Jennings, James. 1994. Blacks, Latinos, and Asians in Urban America: Status and Prospects for Politics and Activism. Westport, CT: Praeger

McClain, Paul D., and Joseph Stewart Jr.
1999. "Can We All Get Along?" Racial and Ethnic Minorities in American Politics. 2nd ed. Boulder: Westview.

Reed, Ishmael. 1993. Japanese by Spring. New York: Penguin Group.

Rich, Wilbur. 1996. The Politics of Minority Coalitions: Race, Ethnicity and Shared Uncertainties. Westport, CT: Praeger.

Takaki, Ronald. 1993. A Different Mirror: $A$ History of Multicultural America. New York: Little, Brown.

X, Malcolm. 1965. The Autobiography of Malcolm $X$ with the assistance of Alex Haley. New York: Grove Press.
Columbus Didn't Discover Us. 1992. Wendall, MA: Turning Tide Productions.

Goin' to Chicago. 1994. San Francisco, CA: California Newsreel.
Hispanics, Their Differences: Myth or Fact. 1998. Princeton, NJ: Films for Humanities and Sciences. 